\title{
Estimation of stature from different head and face measurements among male and female Jatavs of Delhi
}

\author{
Sheetal Sagar and Surinder Nath \\ Department of Anthropology, University of Delhi, Delhi-110007
}

\begin{abstract}
An attempt has been made in the present study to estimate of stature from different body dimensions among male and female Jatavs of Delhi. A total of 300 Jatavs (100males and 200 females) ranging in age 17 to 40 year where measured for the following measurements besides stature, nasal height, nasal breadth, head length, head breadth, ear length.
\end{abstract}

\section{Introduction}

Identification of human skeleton remains is an important aspects of Forensic examination. It includes determining the species of origin, age sex, and stature from bones. Superimposition of skull and photograph have to be carried out in many cases to establish identity. Skeleton or bones and teeth are the hard parts of the body, Thus they escape decay unlike other soft body tissues and

get putrefied and fossilized after considerable lapse of time in nature when preserved under condition to fossilization Hence, even after millions of years we find fossilized bones teeth or whole skeleton, which are require identification. question.

Forensic Anthropologists, during the examination of skeleton remains attempts to answer the following

Whether the bones are Human or nonhuman?

Whether they belong to one or more than one individual?

What would be the age?

What would be the sex?

How tall the person would be?

In identification of human remains, forensic anthropologists help to interpret evidence pertaining to manner or cause of death. Marks on bones provide very important information's to how death occurred. With all evidence of skeleton trauma, it is imperatives recognized and distinguish among the ante mortem, perimortem (around the time of death) postmortem (after death)

Trauma .A skull fracture may be indeed reflecting a blow that could have caused death. Because dried bones have different fracture characteristics than the bone from living organism. It is possible to distinguish between perimortem and postmortem damage by studying details of skeleton lesion.

Many studies have proved beyond doubt that there is positive correlation between stature and length of long bones (Athwal;1963;Patel et al,1964;) (Joshi et al; 1964 ,1965) In similar approach, many workers have demonstrated positive correlation between stature and other body dimensions.

(dug gal et al;1986; Nath et al;1988,1990a,1990b,1997; Anand et al;1990;Singh,1991 Harshwardhana,1996. Kaur 1999:Jain et al 1999.

Though works concerning estimation of stature from long bones as well as from certain body dimensions have been put forward for some of the Indian population, works concerned estimation of stature from facial dimensions are scanty as any part of the human skeleton can be found as the evidences, there is perhaps a need to investigate whether there is any possible significant correlation between stature and facial dimensions in human body. Therefore the present work attempt to estimate stature from facial measurement among the Jatavs of Delhi.

\section{Material and Methods}

The present study has been designed to conduct measurements on male and female of Jatavs inhabiting in different areas of Delhi

In the age range of 17 to 40 years for males and females to formulate multiplication factor and regression equation for estimation of stature using Nasal height, Nasal breath, Head length, head breadth, Ear length.

Thus following measurement has been obtained on each subject 
Using the standard measurement techniques recommended by Martin and Saller (1959), All brook (1961) and Weiner and Louie (1969). All measurements listed have been taken on the left side of the body except stature.

Stature: It is obtained as the projective distance between the standing surface and the highest point on the head $(v-$ vertex) in mid saggital plane when head is obtained in the eye ear plane using anthropometric rod.

Nasal height: It measures the straight distance between nasion and subnasale ( $\mathrm{n}$-sn ) using sliding caliper.

Nasal breadth: It measures from alare to alare using sliding caliper.

Head length: It measures the straight distance between glabella and opisthocranion (the most projecting point on the dorsal surface of the head ) using spreading caliper.

Head breadth: It measures the straight distance between the two eurya (eu)ie maximum breadth wherever found using spreading caliper

Ear length: It measures the distance between superaurale (sa) to subaurale (sba) using spreading caliper.

TABLE : 1 Sex differences among male and female Jatavs of Delhi

\begin{tabular}{|l|l|l|l|l|l|l|}
\hline \multirow{2}{*}{} & \multirow{3}{*}{} & & \multicolumn{3}{|l|}{$\begin{array}{l}\text { MALES } \\
\text { N=100 }\end{array}$} & \multirow{3}{*}{$\begin{array}{l}\text { FEMALES } \\
\text { N=200 }\end{array}$} \\
\cline { 3 - 7 } & & MEAN & S.E & MEAN & S.E & \\
\hline 1 & STATURE & 152.53 & 0.56 & 152.44 & 0.39 & $0.13 \mathrm{NS}$ \\
\hline 2 & NH & 4.77 & 0.06 & 4.88 & 0.23 & $0.55 \mathrm{NS}$ \\
\hline 3 & NBR & 3.9 & 0.05 & 3.75 & 0.15 & $1.1 \mathrm{NS}$ \\
\hline 4 & HEL & 18.7 & 0.12 & 17.9 & 0.09 & $1.57 \mathrm{NS}$ \\
\hline 5 & HBR & 13.9 & 0.07 & 13.44 & 0.06 & $2.2 \mathrm{~S}$ \\
\hline 6 & EL & 5.9 & 0.05 & 6 & 0.11 & $3.66 \mathrm{~S}$ \\
\hline
\end{tabular}

Table 1: shows that the sex differences are significant only for HBR and EL whereas the remaining measurement exhibit has non-significant sex difference.

Table-2 Multiplication factor for estimation of stature among male and female Jatavs of Delhi.

\begin{tabular}{|l|l|l|c|l|l|}
\hline $\begin{array}{l}\text { S.N } \\
\text { O }\end{array}$ & $\begin{array}{l}\text { MEASUREMEN } \\
\text { TS }\end{array}$ & $\begin{array}{l}\text { MULTIPLICATION } \\
\text { FACTOR } \\
\text { (MALES) } \\
\text { MEAN }\end{array}$ & $\begin{array}{l}\text { MULTIPLICATION FACTOR } \\
\text { (FEMALES ) } \\
\text { MEAN }\end{array}$ \\
\hline 1 & NH & 34.14 & 5.25 & 33.17 & 4.40 \\
\hline 2 & NBR & 41.59 & 5.36 & 43.06 & 5.05 \\
\hline 3 & HEL & 8.76 & 0.59 & 8.65 & 0.95 \\
\hline 4 & HBR & 11.80 & 0.77 & 8.60 & 1.86 \\
\hline 5 & EL & 27.07 & 2.59 & 26.45 & 1.00 \\
\hline
\end{tabular}

Table 2: It present the multiplication factor for all the 5 head \& face measurement among male and female Jatavs. The value of multiplication factor exhibit variation for both the sexes. Males shows greater Multiplication factor for $\mathrm{NH}, \mathrm{HBR}$, and EL while female exhibit greater multiplication factor for NBR \& multiplication factor for HEL is the same for both males and females.

\section{Conclusion}

Analysis of data reveals that Jatavs males exhibit greater dimensions for NBR,HEL and HBR than the females, which for the remaining measurements, NH and EL the females have greater dimensions on subjecting the data to t-test it is observed that the sex difference are significant only for HBR and EL whereas the remaining measurement exhibit has non significant sex difference.

And the value of multiplication factor exhibits variation for both the sexes. Males shows greater Multiplication factor for NH, HBR, and EL while female exhibit greater multiplication factor for NBR \& 
multiplication factor for HEL is the same for both males and females.

\section{References}

[1]. ALLBROOK.D. 1961 The estimation of stature in British and East African males based on tibial and ulnar bone lengths.J.For.Med..8:15-28

[2]. ATHAWALE, M.C.1963. Estimation of height from lengths of forearm bones: A study of One hundred Maharashtrian Male Adults of ages between twenty five and thirty years. Am.J.phys.Anthrop.:105-112.

[3]. ANAND, N. 1990 Use of percutaneous measures of body in reconstruction of stature: A Forensic Anthropology Study of Brahmins and Rajputs of Pauri (U.P.) Unpublished Master's Dissertation, Univ. Delhi

[4]. ANAND, N. AND NATH. 1990 Estimation of stature through percutaneous measures of the upper and lower extremities among Rajputs of Pauri Garhwal, Ind. J. For. Sci., 5; 83-89.

[5]. BENJAMIN M. AUERBACH 2010 : American Journal of Anthropology vol. 141, issue 2, 190-207, February 2010 Stature estimation formulae for Indigenous North American Population

[6]. BADKUR, P. AND NATH. 1989. Estimation of bone length and stature using fragmentary measures of humerus bone, Ind. J. For. Sci., 3: 23-35.

[7]. BADKUR, P. AND S. NATH. 1990a. Use of regression analysis in reconstruction of maximum bone length and living stature from fragmentary measures of the ulna. For. Sci. International, 45: 15-26.

[8]. BADKUR, P. AND S. NATH. 1990b. Fragmentary bone measures and regression analysis in prediction of bone length of radius. J. Ind. Acad. For. Med., $12: 45-50$.

[9]. CHANDRA, N.S. AND S. NATH 1984. Estimation of humeral length from a single fragmentary bone measure. J. Ind. Acad. For. Sci., 23: 11-14.

[10]. CHAURASIA, B.D. 1984. Human Osteology. Delhi, CBS.

[11]. CHANDRA, N.S. AND S. NATH. 1985. Reconstruction of femoral and humeral bones lengths usig a fragmentary bone measure. Ind. J. Phys. Anthrop. And Hum. Genet., 11: 123-128.

[12]. DEVI, L.S. 1999. Formulation of multiplication factors for estimation of stature using head and face measurements among female Meiteis of Manipur. Proceedings of Anthropology at the turn of the Century (Feb. $\left.24^{\text {th }}-25^{\text {th }}\right)$, (abstract).

[13]. DUGGAL, N. 1985. Reconstruction of stature on the basis of certain body measurement among Lodhas and Mundas of District Midnapore, West Bengal, Unpublished Master's Dissertation, Univ. Delhi.

[14]. FELDESMAN, M.R. AND J.K. LUNDY. 1987. New stature estimates in some Plio - Pleistocene hominids. Am. J. Anthrop., 72: 198 (abstract).

[15]. FELDESMAN, M.R. AND J.K. LUNDY. 1988. Stature Estimates for some Plio - Pleistocene fossil hominids. J. Hum. Evol., 17: $583-596$

[16]. GORDON, C.C. and J.E. Buikstra. 1992. Linear models for the prediction of stature from foot and boot dimensions. J. For. Sci., 37: $771-782$.

[17]. GUPTA, G.D. AND S. NATH. 1996. Estimation of femoral and tibial lengths from fragmentary dimensions. Police Research and Development, Qr. I : $41-45$.

[18]. GUPTA, G.D. AND S. NATH. 1998. Determination of humeral length from its fragmentary dimensions. Proceedings of International Conference of Forensic Medicine and XIXth Annual Confernece of Indian Academy of Forensic Medicine - 98, (Forensic Anthropology Section).

[19]. JAIN, P. 1999. Estimation of stature form various body dimensions among Jains of Delhi. Unpublished Thesis, Univ. Delhi.

[20]. JAIN, P. AND S. NATH. 1997. Estimation of stature through upper and lower limb dimensions among Brahmins of Kumaon. Ind. J. Phys. Anthrop. And Hum. Gent., 20 : $163-168$.

[21]. JAIN, P., S. KAUR AND S. NATH 1998a. Estimation of stature through hand and foot lengths among female Jats of Delhi. Proceedings of International Academy of Forensic Medicine and XIXth Annual Conference of Indian Academy of Forensic Medicine-98. (Forensic Anthropology Section).

[22]. JAIN, P., S. KAUR AND S. NATH. 1998b. Formulation of multiplication factors from hand and foot lengths for estimation of stature among Warli males of Maharashtra. Proceedings of International Conference of Forensic Medicine and XIXth Annual Conference of Indian Academy of Forensic Medicine - 98, (Forensic Anthropology Section).

[23]. JANTZ, R.L. 1992. Modification of the Trotter and Gleser female stature estimation formula. J. For. Sci., $37: 1230$ - 1235.

[24]. JANTZ, R.L., D.R. HUNT AND L. MEADOWS. 1995. The measure and mismeasure of the tibia: Implications for Stature Estimation. J. For. Sci., 40: $758-761$. (abstract).

[25]. KAUR, S., P. Jain and S. Nath. 1998. Reconstruction of stature from hand, mid - finger and foot lengths among Brahmins of Kumaon. Proceedings of International Conference of Forensic Medicine and XIXth Annual Conference of Indian Academy of Forensic Medicine-98, (Forensic Anthropology Section).

[26]. KAUR, S., P. JAIN AND S. NATH. 1999a. Use of conventional and non conventional dimensions of upper and lower limbs to formulate regression equations for prediction of stature among male Brahmins of Kumaon. In Press.

[27]. KAUR, S., P. JAIN S. NATH. 1999b. Use of upper and lower limb dimensions in prediction of stature among Warli males of Maharashtra. In Press.

[28]. LUNDY, J.K. 1986. Physical Anthropology in Forensic Medicine. Anthropology Today, 2: $14-17$.

[29]. LUNDY, J.K. 1988a. A report on the use of Fully's anatomical method to estimate stature in military skeletal remains. J. For. Sci., $33 ; 1045-1049$.

[30]. MANN. R.W. AND D.H. UBELAKER, 1990. The Forensic Anthropologist. F.B.I. Law Enforcement Bulletin,., 59 : 20 - 23.

[31]. MANT, A.K. 1984. Identification of living and dead. In A.K. Mant. (ed.) Taylor's Principles and Practices of Medical Jurisprudence. $13^{\text {th }}$ edition, Churchill Livingstone, New York.

[32]. MEADOWS, L. AND R.L. JANTZ. 1992. Estimation of stature from metacarpal lengths. C. For. Sci. JFSCA, 37 : 147 - 154

[33]. MEADOWS, L. AND R.L. JANTZ. 1995. Allometric secular change in the long bones from 1800s to the present. J. For. Sci., 40: $762-767$ (abstract).

[34]. NATH, S. 1987. Forensic Anthropology: A New Dimension to the Study of Skeletal Material: Spectra of Anthropological Progress, 9: $35-40$.

[35]. NATH, S. 1988a. Formulation of linear regression equations for prediction of stature through percutaneous lengths of radius, ulna and tibia among Lodha males. Unpublished.

[36]. NATH, S. 1988b. Multiple regression equations for estimation of stature using percutaneous lengths of the Baigas and the Gonds of Madhya Pradesh. Unpublished. 
[37]. NATH, S.1989. An Introduction to Forensic Anthropology. Gian Publishing House, New Delhi.

[38]. NATH, S. 1992. Forensic Anthropology in Mahajan, A. and S. Nath, (eds.) Application Aresa of Anthropology. Reliance Publishing House, New Delhi

[39]. NATH, S. 1993. Anthropometry - The Measurement of Body Size, Shape and Form. Friends Publication, Delhi

[40]. NATH, S. 1996. Forensic Anthropology. Asthma Prakashan, Delhi.

[41]. Nath, S. 1997. Estimation of stature through hand and foot length among Jats of Rajasthan. Police Research and Development, Qr. IV: $20-22$.

[42]. NATH S. 2000. Reconstruction of tibial length and stature from fragmentary dimensions. J.Hum. Ecol., 11 (1):167 - 176.

[43]. NATH, S., S. AGGARWAL AND G.D. GUPTA. 1998a. Prediction of crownheel length (CHL) among neonates. Proceedings of International Conference of Forensic Medicine and XIXth Annual Conference of Indian Academy of Forensic Medicine - 98, (Forensic Anthropology Section.)

[44]. PHILIP, T.A. 1988. Foot size for predicting stature of males. J. Ind. Acad. For. Sci., 27: $30-39$.

[45]. PHILIP, T.A. 1989. Stature from foot size of females. St. John's Med. Col. J. Med., 2: $21-25$.

[46]. RAJNI. 1988. Reconstruction of stature on the basis of percutaneous measures of the upper and the lower extremities among Punjabi and Baniya females. Unpublished M. Phil Dissertation, Univ. of Delhi.

[47]. RAO, K.V.S,. G.D. GUPTA AND V.N. SEHGAL. 1989a. Determination of human long bones of hands from their fragments. For. Sci. Int., 40: $279-284$.

[48]. RAO, K.V.S., G.D. GUPTA AND V.N. SEHGAL. 1989b. Determination of length of human upper limb long bones from their fragments. For. Sci. Int., 41: $219-223$.

[49]. ROBBINS, L.M. 1986. Estimating height and weight from size of foot prints. J. For. Sci., 31: 143 - 152.

[50]. ROSING, F.W. 1983. Stature estimation in Hindus. Homo, 34: $168-171$.

[51]. SACHDEVA, M.P., S. NATH AND A.MATHEW. 1998. Reconstruction of stature from upper and lower limb bone dimensions among Brahmins and Rajputs of District Pithoragarh, U.P.in Press.

[52]. SCIULLI, P.W. AND M.J. GIESEN. 1993. An update on stature estimation in prehistoric native Americans of Ohio. Am. J. Phys. Anthrop., 92: 395 - 399.

[53]. SCIULLI, P.W., K.M. SCHNEIDER AND M.C. MAHANEY. 1990. Stature estimation in prehistoric native Americans of Ohio. Am. J. Phy. Anthrop., 83: $275-280$.

[54]. SETHI, V. AND S. NATH. 2000. Estimation of stature through hand and foot lengths among Punjabi females of Delhi. South Asian Anthropologist 21: $61-71$.

[55]. SHARMA, B.R. 1980. Footpritns tracks and trials in criminal Investigations and Trials. Central Law Agency; Allahabad.

[56]. SHITAL, M.O. 1983 Estimation of stature by long bones of Chinese male adults in South China. Acta Anthrop. Sin., 2: $80-85$

[57]. SHROFF, A.G. AND S. FAKHRUDDIN. 1986. Relationship between the length of humerus and its segments. J Anant. Soc. India, 35: $109-114$.

[58]. SHULIN, P. AND Z. FANGWU. 1983. Estimation of stature from skull, clavicle, scapula and ox coax of male adult of Southern China. Acta. Anthrop. Sin., 2: $253-259$.

[59]. SIMMOKNS, T., R.L. JANTZ AND W.M. BASS. 1990 Stature Estimation from Fragmentary femora: A Revision of the Steele Method. J. For.

[60]. SNOW, C.C. 1982a. Forensic Anthropology. Ann. Rev. Anthrop., 11: 97 - 131.

[61]. SNOW, C.C. 1982b. Forensic Anthropology. In J.A. Cottone and S.M. Standish, (eds.) Outline of Forensic Dentistry. London, Yearbook Medical Publishers, Inc.

[62]. SNOW, C.C. 1995. Murder Most Foul. The Sciences, 35: 16-20.

[63]. TROTTER, M. 1970. Estimation of Stature from entact bones. In T.D. Stewart, (ed.) Personal Identification in Mass Disasters, pp. 71-83. National Museum of Natural History, Washington.

[64]. TROTTER, M. and G.C. GLESER. 1952. Estimation of stature from long bones of American Whites \& Negroes. Am. J. Phys. Anthrop., 10: 463-514.

[65]. UBELANKAR, D.H. 1996. Skeletons testify : Anthropology in Forensic Sciences AAPA Luncheon Address: April 12, 1996. Yrbk. Phys. Anthrop., $39: 229-244$

[66]. WEINER, J.S. AND J.A. LOURIE, 1969. Human Biology: A Guide to field methods. IBP Handbook No. 9, Blackwell Scientific Publication, Oxford.

[67]. WAHANE, ABHILASHA, FULPATEL, M.P. KAMBLE Medico-Legal update - An International Journal Year : 2010, volume 10, Website issue: 2 stature estimation from the length of Head in living adults.

http://upgov.nic.in/

www.mapsofindia.cm

http://www.webindia123.com

www.pubmed.com 